\title{
The soil-plant relationship of nitrogen use in three tropical tree species
}

\author{
E. F. L. Pereira-Silva, E. Hardt, and A. O. Fernandes \\ Faculdade Municipal "Professor Franco Montoro", Rua dos Estudantes, Cachoeira de Cima, 13843-971, \\ Mogi Guaçu, São Paulo, Brazil \\ Correspondence to: E. F. L. Pereira-Silva (candeya@gmail.com)
}

Received: 2 December 2011 - Revised: 20 August 2012 - Accepted: 6 September 2012 - Published: 1 October 2012

\begin{abstract}
We characterized and compared the use of nitrate $\left(\mathrm{N}-\mathrm{NO}_{3}^{-}\right)$, in three recognized pioneer and secondary tropical species, analyzing their relationships with the availability of inorganic nitrogen in the soil of a riparian forest. We tested the hypothesis that pioneer species of the ecological succession (Cecropia glaziovi - Cgl) would be more responsive to $\mathrm{N}^{-\mathrm{NO}_{3}^{-}}$available and would have high nitrate reductase activity (NRA) in leaves while secondary species (Inga marginata - Ima and Hymenaea courbaril - Hco) would have less responsiveness and would have lower levels of this enzyme on its leaves. We evaluated, tested and compared the $\mathrm{NRA}$ and $\mathrm{N}-\mathrm{NO}_{3}^{-}$content in leaves and xylem sap of each species. We measured $\mathrm{N}-\mathrm{NO}_{3}^{-}$and $\mathrm{N}-\mathrm{NH}_{4}^{+}$content in the soil. The results for $\mathrm{Cgl}$ showed an $\mathrm{N}_{-} \mathrm{NO}_{3}^{-}$content of xylem sap that met the demand of NRA and were correlated with inorganic soil nitrogen, showing the responsiveness of species to $\mathrm{N}^{-\mathrm{NO}_{3}^{-}}$. Hco was verified as less responsive to assimilation and high $\mathrm{N}_{-} \mathrm{NO}_{3}^{-}$content in leaves. The species Ima showed an intermediate behaviour, which suggests the possibility of use of other nitrogen forms. The ecophysiological behaviours of the plants were related to the seasonal variation and indicate that these plants use strategies with different responsiveness to the use of soil N-NO- . In this sense and considering that these species are typically used in ecological restoration projects in Brazil, the knowledge of a strategy for nitrogen use specific to each of them can assist in choosing the species appropriate to the edaphic conditions of the environment.
\end{abstract}

1 Introduction

The comprehension of soil-plant nutrient relationships and adaptive processes of certain species has been of utmost importance to the success of ecological restoration. In this sense, scientific awareness of the basic patterns of nitrogen source utilisation by tree species is essential in order to understand species' adaptation and distribution in different environmental conditions (Koyama et al., 2001). Existing evidence highlights the fact that plants use defined strategies for acquisition and use of nitrogen, according to diversity of nitrogen forms available and their quantity variation and quality in the environment (Stewart, 1986; Stewart et al., 1993; Kielland, 1994; Schmidt and Stewart, 1998; Usman et al., 2000; Aidar et al., 2003; Pereira-Silva et al., 2006; Schimann et al., 2008). Thus, depending on soil conditions, one can choose the best species in terms of responsiveness to the forms of nitrogen present.

Studies with plant tissue represent an effective technique for determination of plants' nutritional status. Some relevant examples on methods to estimate the nutrient status by direct measurements can be pointed out: (i) tests for determination of nitrate $\left(\mathrm{N}-\mathrm{NO}_{3}^{-}\right)$in leaves or roots give clear responses for assessment of plants' nitrogen status (Hartz et al., 2000), being indicators of consumption and accumulation of $\mathrm{N}-\mathrm{NO}_{3}^{-}$, respectively; (ii) analyses of $\mathrm{N}_{-} \mathrm{NO}_{3}^{-}$in the xylem sap are also relevant to measure the transport of nitrogen in transit to a site of assimilation before metabolic conversions occur (Malavolta et al., 1997; Sodek, 2004); (iii) responsiveness of a known kind $\mathrm{N}_{-} \mathrm{NO}_{3}^{-}$is especially important in disturbed soils, where the conditions can change radically, and soil nitrogen can be converted mainly to $\mathrm{N}^{-N_{3}^{-}}$(Kronzuchker et al., 1997); (iv) several species of trees using soil 
$\mathrm{N}-\mathrm{NO}_{3}^{-}$and with high activity of nitrate reductase activity (NRA) in leaves (Stewart et al., 1993) perform as good indicators of absorption and utilisation of $\mathrm{N}^{-\mathrm{NO}_{3}^{-}}$by the plant (Lee and Stewart, 1978; Pate, 1980; Smirnoff et al., 1984).

In numerous ecosystems, research has been carried out regarding nitrogen use by plants in relation to ecological succession (Haines, 1977; Lamb, 1980; Robertson and Vitousek, 1981; Smith and Rice, 1983; Smirnoff and Stewart, 1985; Tilman and Wedin, 1991; Stewart et al., 1990, 1992; Schimann et al., 2008). In tropical and sub-tropical regions, there is a preference for reduction of $\mathrm{N}^{-\mathrm{NO}_{3}^{-}}$in leaves for plants, especially for plants with high photosynthetic capacity such as those considered to be pioneer species (Kronzucker et al., 1997; Taiz and Zeiger, 2002). In tropical forests of Australia, Stewart (1986) proposed the organization of species in a pioneer group - that occurred in locations with elevated luminosity, and that had relatively high levels of NRA in the leaves - and in a climax group - that occurred in environments with low luminosity and had low levels of NRA in the leaves. Later, Aidar et al. (2003) and Pereira-Silva et al. (2011) found that in the Brazilian Atlantic Forest some trees have distinct capacities for $\mathrm{N}_{-} \mathrm{NO}_{3}^{-}$reduction in the leaves according to their category of succession (pioneer or secondary).

Research about physiological responses of nitrogen use for restoration in functional species is scarce, especially when considering soil-plant relations to $\mathrm{N}^{-\mathrm{NO}_{3}^{-}}$use. Furthermore, there is a lack of literature regarding processes and relations of nitrogen use for species commonly used in environmental recuperation, particularly if the purpose is ecological restoration. In this context, this article draws upon the assumption that species clearly defined in literature as belonging to a particular type of succession have a typical soil-plant relationship for nitrogen use. Hence, our analysis characterizes and compares the nitrogen metabolism - with focus on the use of $\mathrm{N}^{-\mathrm{NO}_{3}^{-}}$- of three pioneer and secondary species, analyzing their relationship with the availability of inorganic nitrogen in the soil of a riparian forest in southeast Brazil. Considering that these species are typically used in ecological restoration projects in this country, the confirmation of a strategy for nitrogen use specific to each of them can assist in selecting appropriate species according to the soil conditions of the environment.

This study is based on the hypothesis that species clearly defined in the literature as belonging to a particular type of succession present a characteristic soil-plant nitrogen use. Thus, this study characterizes and compares nitrogen metabolism, especially the use of $\mathrm{N}^{-\mathrm{NO}_{3}^{-}}$in three recognized pioneer and secondary species, analyzing their relationships with the availability of inorganic nitrogen in the soil of a riparian forest in southeastern Brazil. Considering that these species are typically used in ecological restoration projects in Brazil, the knowledge of a strategy for nitrogen use specific to each of them can assist in choosing the species appropriate to the edaphic conditions of the environment.

\section{Material and methods}

\subsection{Study area and field experiment}

The study was carried out in the flooded area of the Mogi-Guaçu River in the State of São Paulo $\left(22^{\circ} 22^{\prime} 42^{\prime \prime}\right.$ S; $46^{\circ} 53^{\prime} 48^{\prime \prime} \mathrm{W}$; at $609 \mathrm{~m}$ altitude), where the original prevalent vegetation was savannah with a type of riparian forests along the rivers (Delitti and Burger, 2000).

The regional climate is tropical, Köppen type Cwa, with rainy summers and seasonal winter droughts. The mean annual temperature and accumulated rainfall ( $n=365$ days) were $27.2^{\circ} \mathrm{C}$ and $1335.8 \mathrm{~mm}$, respectively (CIIAGRO online, 2010). Due to the seasonal nature of the area, the experiments on the soil-plant relationship of nitrogen use were carried out during the dry (9 November 2010) and wet (26 November 2010) seasons. Accumulated rainfall (AR) and potential evapotranspiration (EVP) were calculated for dry and wet seasons (CIIAGRO on-line, 2010).

\subsection{Species studied}

- Cecropia glaziovi is a heliophilous, pioneer species (PS) with a life history characterized by a short duration time (less than $10 \mathrm{yr}$ ). This species is found in large gaps and open areas, the edges of rivers and floodplains, and they produce large numbers of small seeds dispersed by birds and bats.

- Inga marginata is a tropical leguminous species that is very common in the margins of rivers and streams. They can grow on degraded land, although it has a preference for wetlands and fertile soils. It is considered an early secondary species (ESS), and this tree has a life expectancy characterized by a medium duration (around 10 to $25 \mathrm{yr})$.

- Hymenaea courbaril is considered to be tropical leguminous species. They are late secondary successional (LSS) trees with a life expectancy characterized by a long duration (more than $50 \mathrm{yr}$ ). This species lives in the riparian forest, near water and can grow on degraded land, although it prefers wetlands and fertile soils.

\subsection{Soil sampling and analysis}

Rates of inorganic nitrogen were determined for the dry $(n=8)$ and wet $(n=8)$ seasons from intact soil samples collected in a 0 to $5 \mathrm{~cm}$ soil horizon at locations near the species under investigation. The samples were placed in numbered plastic bottles and immediately sent to the Campinas Agronomic Institute, Brazil, where they were kept in a $-20^{\circ} \mathrm{C}$

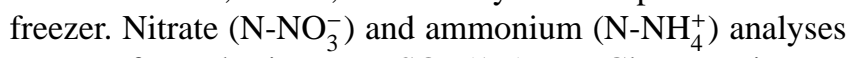
were performed using a $\mathrm{Na}_{2} \mathrm{SO}_{4}(1 \mathrm{~N})+\mathrm{HgCl}_{2}$ extraction solution with the addition of $\mathrm{C}_{6} \mathrm{H}_{10} \mathrm{O}_{8} \mathrm{Na}_{2} \mathrm{~S}_{2}(0.01 \%)$, according to Onken and Sunderman (1977); after extraction the 
Table 1. Chemical and granulometric analyses of the typical dystrophic Red-Yellow Argisol - PVAd. Data from Genú et al. (2010).

\begin{tabular}{|c|c|c|c|c|c|c|c|c|c|c|c|c|c|c|}
\hline depth & $\mathrm{pH}$ & MO & $\mathrm{P}$ & $\mathrm{K}$ & $\mathrm{Ca}$ & $\mathrm{Mg}$ & $\mathrm{Al}$ & $\mathrm{H}+\mathrm{Al}$ & SB & CTC & $\mathrm{V} \quad \mathrm{m}$ & Sand & Silt & Clay \\
\hline $\mathrm{cm}$ & $\mathrm{CaCl}_{2}$ & $\mathrm{~g} \mathrm{~kg}^{-1}$ & $\mathrm{mg} \mathrm{kg}^{-1}$ & \multicolumn{7}{|c|}{$\operatorname{mmol}_{\mathrm{c}} \mathrm{kg}^{-1}$} & $\%$ & \multicolumn{3}{|c|}{$\mathrm{g} \mathrm{kg}^{-1}$} \\
\hline $0-20$ & 5.4 & 20 & 57 & 1.0 & 40 & 6.0 & 2.0 & 22 & 47.0 & 69.0 & $\begin{array}{ll}68 & 4\end{array}$ & 530 & 140 & 330 \\
\hline
\end{tabular}

samples were read with a spectrophotometer $(430 \mathrm{~nm})$ and quantified $\left(\mathrm{mg} \mathrm{kg}^{-1}\right)$ using a standard curve.

\subsection{Collection of plant material and analysis}

Fresh leaf $(5 \mathrm{~g})$ and xylem sap $(5 \mathrm{ml})$ samples were collected from C. glaziovi $(n=3)$, I. marginata $(n=3)$ and $H$. courbaril $(n=3)$ during the first hours of daylight, from 07:00 to 10:00 LT, when there is an increase in leaf nitrate reductase activity (NRA) and in the plant transpiration flux that leads the $\mathrm{N}_{-} \mathrm{NO}_{3}^{-}$leaf to the leaves. The leaves were removed from the middle third of healthy branches and kept at $4{ }^{\circ} \mathrm{C}$ until the beginning of the laboratory analyses. The defoliated branches were connected to a vacuum pump for xylem sap extraction and subsequent $\mathrm{N}-\mathrm{NO}_{3 \text { xy }}^{-}$content analysis. All analyses were performed in duplicate for each individual.

For the NRA analyses, the leaves were chopped and transferred to assay tubes for incubation in the absence of light, following infiltration under vacuum conditions in a $0.1 \mathrm{M}$ phosphate buffer $\left(\mathrm{K}_{2} \mathrm{HPO}_{4}\right)$ containing $1 \%$-propanol $(v / v)$ and $100 \mathrm{mM}$ potassium nitrate $\left(\mathrm{KNO}_{3}\right)$, according to Stewart (1986). Activity was determined by colorimetric method $(540 \mathrm{~nm})$ and expressed in pkat $\mathrm{g} \mathrm{FW}^{-1}$.

Leaf nitrate content $\left(\mathrm{N}^{-} \mathrm{NO}_{3}^{-}\right.$leaf $)$was determined after extraction of $0.5 \mathrm{~g}$ of leaves by immersion in $5 \mathrm{ml}$ of methanol for $24 \mathrm{~h}$ at room temperature followed by storage at $-20^{\circ} \mathrm{C}$. Both the methanol leaf extract and the xylem sap $\left(\mathrm{NO}_{3 \mathrm{xy}}^{-}\right)$of each sample were used for the determination of $\mathrm{N}^{-\mathrm{NO}_{3}^{-}}$by the colorimetric $(410 \mathrm{~nm})$ salicylic acid method (Cataldo et al., 1975). Data for N-NO$-\mathrm{N}_{3}^{-}$were expressed as $\mu \mathrm{mol} \mathrm{ml}^{-1}$ of sap and $\mu \mathrm{mol} \mathrm{g} \mathrm{FW}^{-1}$ of leaves.

\subsection{Statistical tests}

The One-Way ANOVA with Duncan's test a posteriori was used to compare among the species. The nitrogen soil-plant variables, $\mathrm{NRA}, \mathrm{NO}_{3}^{-}$leaf, $\mathrm{NO}_{3}^{-}$xy and $\mathrm{NO}_{3}^{-}$soil, were compared by Pearson's correlation coefficients $(\alpha=0.05)$ in order to find pair-wise relationships.

We used factorial discriminant analysis (FDA) to order and simplify the information on a two-dimensional map and understand the relationships among variables and species. The FDA consists of axes that determine the optimal separation of the predefined groups in space, maximizing the differences between variables and groups. These analyses were carried out using the software XLStat Addinsoft $₫ 2007$ (experimental version).
Table 2. Mineral nitrogen content $\left(\mathrm{N}-\mathrm{NO}_{3}^{-}\right.$and $\left.\mathrm{N}-\mathrm{NH}_{4}^{+}\right)$, accumulated rainfall $(\mathrm{AR})$ and potential evapotranspiration (EVP) during dry and wet seasons.

\begin{tabular}{|c|c|c|c|c|c|}
\hline \multirow{2}{*}{ Season } & \multirow[b]{2}{*}{$n$} & $\mathrm{~N}-\mathrm{NO}_{3}^{-}$ & $\mathrm{N}-\mathrm{NH}_{4}^{+}$ & $\mathrm{AR}^{*}$ & $\mathrm{EVP}^{*}$ \\
\hline & & \multicolumn{2}{|c|}{$\mathrm{N} \mathrm{mg} \mathrm{kg}^{-1}$} & \multicolumn{2}{|c|}{$\mathrm{mm}$} \\
\hline wet & 8 & 14.0 & 19.1 & 65.1 & 17.0 \\
\hline dry & 8 & 5.9 & 20.4 & 15.7 & 11.0 \\
\hline
\end{tabular}

\section{Results}

The area's pedological characteristics have been described by Genú et al. (2010) and are shown in Table 1. The amount of inorganic nitrogen in the soil during the wet season was higher compared to the dry season and was influenced by the high $\mathrm{NO}_{3}^{-}$content provided by the greater amount of water entering the soil during the summer (Table 2). The results showed the predominance and constancy of $\mathrm{N}^{-\mathrm{NH}_{4}^{+}}$in comparison to $\mathrm{N}^{-\mathrm{NO}_{3}^{-}}$in the both seasons.

We observed some important characteristics of nitrogen ecophysiology, with a focus on $\mathrm{N}-\mathrm{NO}_{3}^{-}$, for the analyzed species (Table 3). The responsiveness was investigated in two steps of $\mathrm{N}-\mathrm{NO}_{3}^{-}$utilisation for plants, the $\mathrm{N}-\mathrm{NO}_{3}^{-}$transport and the reduction in the leaves.

C. glaziovi $(\mathrm{Cgl})$ showed an affinity for $\mathrm{N}^{-\mathrm{NO}_{3}^{-}}$, indicated mainly by a higher NRA transportation $\left(\mathrm{N}^{-\mathrm{NO}_{3}^{-}}\right.$xy $)$and, in the dry season, $\mathrm{N}^{-\mathrm{NO}_{3}^{-}}$leaf. This nitrogen use behaviour was quite different from the other two species studied, as confirmed by the formation of ANOVA groups (Table 3). For $I$. marginata (Ima) and H. courbaril (Hco) a lower NRA was observed, as well as a low content in the xylem's sap and equivalent values of foliar $\mathrm{NO}_{3}^{-}$, principally in the wet season (Table 3).

Regarding the relationships between consumption, accumulation and transport of $\mathrm{N}^{-\mathrm{NO}_{3}^{-}}$, in $\mathrm{Cgl}$ and Ima, there was

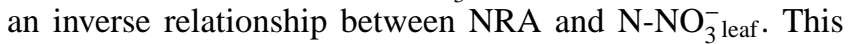
means that a higher NRA was accompanied by a lower N$\mathrm{NO}_{3}^{-}$leaf content. Probably as a function of low $\mathrm{N}^{-\mathrm{NO}_{3}^{-}}$concentrations, Ima also showed an inverse relationship between $\mathrm{N}-\mathrm{NO}_{3}^{-}$leaf and $\mathrm{N}-\mathrm{NO}_{3}^{-}$xy. In contrast, Hco did not show significant $\mathrm{N}^{-\mathrm{NO}_{3}^{-}}$use (Table 4).

Intrinsic behaviours were observed in the relationship between the variables nitrogen use and $\mathrm{N}^{-} \mathrm{NO}_{3}^{-}$availability in the soil. The use of $\mathrm{N}^{-\mathrm{NO}_{3}^{-}}$by $\mathrm{Cgl}$ was significantly related 
Table 3. One-Way ANOVA comparison tests with Duncan's test a posteriori. Mean \pm SD to nitrate reductase activity (NRA), Nitrate in leaves $\left(\mathrm{N}_{-} \mathrm{NO}_{3}^{-}\right.$leaf $)$and in xylem sap $\left(\mathrm{N}_{-} \mathrm{NO}_{3}^{-}\right.$xy $)$for $\mathrm{Cgl}$ (Cecropia glaziovi), Ima (Inga marginata) and Hco (Hymenaea courbaril). Means indicated by different letters are statistically significant at $5 \%$. nv - not verified.

\begin{tabular}{|c|c|c|c|c|c|c|c|c|c|c|c|c|c|c|}
\hline \multirow{3}{*}{$\begin{array}{l}\text { Species } \\
\mathrm{Cgl}\end{array}$} & \multirow{3}{*}{$\begin{array}{l}n \\
6\end{array}$} & \multirow{3}{*}{$\begin{array}{l}\text { Season } \\
\text { wet }\end{array}$} & \multicolumn{4}{|c|}{ NRA } & \multicolumn{4}{|c|}{$\mathrm{N}-\mathrm{NO}_{3}^{-}$leaf } & \multicolumn{4}{|c|}{$\mathrm{N}-\mathrm{NO}_{3}^{-}$xy } \\
\hline & & & \multicolumn{4}{|c|}{ pkat $g^{-1} \mathrm{FW}$} & \multicolumn{4}{|c|}{$\mathrm{mol} \mathrm{g}^{-1} \mathrm{FW}$} & \multicolumn{4}{|c|}{$\mathrm{mol} \mathrm{ml}^{-1}$} \\
\hline & & & 216.1 & \pm & 37.6 & B & 11.8 & \pm & 2.6 & A & 1.23 & \pm & 0.45 & B \\
\hline & & dry & 151.3 & \pm & 29.0 & B & 15.3 & \pm & 0.2 & C & & nv & & \\
\hline \multirow[t]{2}{*}{ Ima } & 6 & wet & 69.0 & \pm & 6.3 & A & 9.7 & \pm & 0.5 & A & 0.04 & \pm & 0.02 & A \\
\hline & & dry & 96.7 & \pm & 3.6 & A & 7.3 & \pm & 1.9 & A & 0.07 & \pm & 0.03 & A \\
\hline \multirow[t]{2}{*}{ Hco } & 6 & wet & 50.7 & \pm & 16.5 & A & 10.2 & \pm & 3.8 & A & 0.02 & \pm & 0.01 & A \\
\hline & & dry & 108.8 & \pm & 25.6 & A & 10.4 & \pm & 0.3 & B & 0.07 & \pm & 0.04 & A \\
\hline
\end{tabular}

Table 4. Pearson's correlation matrix of nitrogen use variables. Nitrate reductase activity (NRA), nitrate in leaves $\left(\mathrm{N}^{-\mathrm{NO}_{3}^{-}}\right.$leaf $)$, xylem sap $\left(\mathrm{N}_{-} \mathrm{NO}_{3}^{-}\right.$xy $)$and in soil $\left(\mathrm{N}_{-} \mathrm{NO}_{3}^{-}\right.$soil $)$for $\mathrm{Cgl}$ (Cecropia glaziovi), Ima (Inga marginata) and Hco (Hymenaea courbaril). nv - not verified. Bold data represent a significant $\mathrm{p}$-value.

\begin{tabular}{|c|c|c|c|c|c|c|c|c|c|}
\hline \multirow{2}{*}{ Species } & \multirow{2}{*}{$n_{\text {plant }}$} & & \multicolumn{2}{|c|}{ NRA vs. $\mathrm{N}^{-\mathrm{NO}_{3}^{-} \text {leaf }}$} & \multicolumn{2}{|c|}{ NRA vs. N-NO ${ }_{3 x y}^{-}$} & \multicolumn{2}{|c|}{$\mathrm{N}-\mathrm{NO}_{3}^{-}$xy vs. $\mathrm{N}-\mathrm{NO}_{3}^{-}$leaf } & \multirow{2}{*}{$\alpha$} \\
\hline & & & $r$ & $p$ & $r$ & $p$ & $r$ & $p$ & \\
\hline $\mathrm{Cgl}$ & 6 & & -0.97 & 0.007 & \multicolumn{2}{|c|}{$\mathrm{nv}$} & \multicolumn{2}{|c|}{$\mathrm{nv}$} & \\
\hline Ima & 6 & & -0.84 & 0.036 & 0.86 & 0.059 & -0.90 & 0.037 & \\
\hline \multirow[t]{3}{*}{ Hco } & 6 & & 0.33 & 0.585 & 0.80 & 0.107 & -0.06 & 0.921 & \\
\hline & & & \multicolumn{2}{|c|}{ NRA vs. N-NO ${ }_{3}^{-}$soil } & \multicolumn{2}{|c|}{$\mathrm{N}-\mathrm{NO}_{3}^{-}$leaf $\mathrm{vs.} \mathrm{N}-\mathrm{NO}_{3}^{-}$soil } & \multicolumn{2}{|c|}{$\mathrm{N}-\mathrm{NO}_{3 \text { xy }}^{-}$vs. $\mathrm{N}-\mathrm{NO}_{3}^{-}$soil } & 0.005 \\
\hline & & $n_{\text {soil }}$ & $r$ & $p$ & $r$ & $p$ & $r$ & $p$ & \\
\hline $\mathrm{Cgl}$ & 6 & 8 & 0.90 & 0.029 & -0.94 & 0.013 & & & \\
\hline Ima & 6 & 8 & -0.96 & 0.008 & 0.84 & 0.036 & -0.78 & 0.118 & \\
\hline Hco & 6 & 8 & -0.82 & 0.091 & -0.05 & 0.941 & -0.65 & 0.165 & \\
\hline
\end{tabular}

to the availability of this ion in the soil. The consumption availability relationship was positive, while the accumulation availability was negative, which signifies that this species responds to $\mathrm{N}_{-} \mathrm{NO}_{3}^{-}$in the soil with more NRA and, consequently, less $\mathrm{N}_{-} \mathrm{NO}_{3}^{-}$leaf in the plant. For Ima, there was a less significant and inverse relationship, suggesting an intermediate responsiveness to $\mathrm{N}-\mathrm{NO}_{3}^{-}$. In contrast, the lack of correlation between the availability and use of $\mathrm{N}-\mathrm{NO}_{3}^{-}$shows a low responsiveness of Hco to this ion (Table 4).

Results of the FDA rejected the null hypothesis of equality of species groups' vectors (Fig. 1). The bidimensional scores observed in the FDA showed that $\mathrm{Cgl}$ was distant from the Ima and Hco groups and more related to NRA, N-NO ${ }_{3}^{-}$leaf and $\mathrm{N}_{-} \mathrm{NO}_{3 x y}^{-}$. This reinforced the hypothesis that $\mathrm{Cgl}$ have a greater ability to use $\mathrm{N}-\mathrm{NO}_{3}^{-}$for nitrogen transport in leaves.

\section{Discussion}

The lower concentrations and variations of $\mathrm{N}^{-\mathrm{NO}_{3}^{-}}$in the soil demonstrate high mobility by mass flow and/or consumption. The greater availability of this ion during the wet season is influenced by precipitation and humidity (Table 2). Changes in precipitation regimes, through changes in soil moisture, significantly altered the nitrogen availability processes in the soil (Dijkstra et al., 2010 and Niboyet et al., 2011). Furthermore, this variation is also influenced by the prevailing soil in the area described by Genú et al. (2010) as typical dystrophic Red-Yellow Argisol - PVAd (Tables 1 and 2). This soil has a high water retention capacity, with the distinctiveness of moderate fertility in the region (V\% $>50 \%$ - EMBRAPA, 2006). The soil type can also explain the predominance and constancy of $\mathrm{N}_{-} \mathrm{NH}_{4}^{+}$in both seasons (Table 2). The presence of clay is an important factor in the adherence and immobility of these ions in soil solution (Nieder and Benbi, 2008).

The coexistence of $\mathrm{NO}_{3}^{-}$and $\mathrm{NH}_{4}^{+}$observed may have a positive synergistic effect in plants (Kronzucker et al., 1997). Plants generally develop better in mixed nitrogen compositions, absorbing mineral nitrogen $\left(\mathrm{N}-\mathrm{NO}_{3}^{-}\right.$and $\left.\mathrm{N}-\mathrm{NH}_{4}^{+}\right)$, nitrogen oxides $\left(\mathrm{NO}_{\mathrm{x}}\right)$, molecular nitrogen $\left(\mathrm{N}_{2}\right.$ from symbiotic fixation) or organic nitrogen, with different energetic costs for the metabolization of each nitrogen form (Stewart et al., 1993, Marschner, 1995; Pereira-Silva et al., 2006). It is believed that there is a tendency for increased responsiveness to nitrogen forms that have lower metabolic costs for the plant. Although not yet consolidated, the literature presents evidence that $\mathrm{Cgl}$ preferentially use this ion. This knowledge 

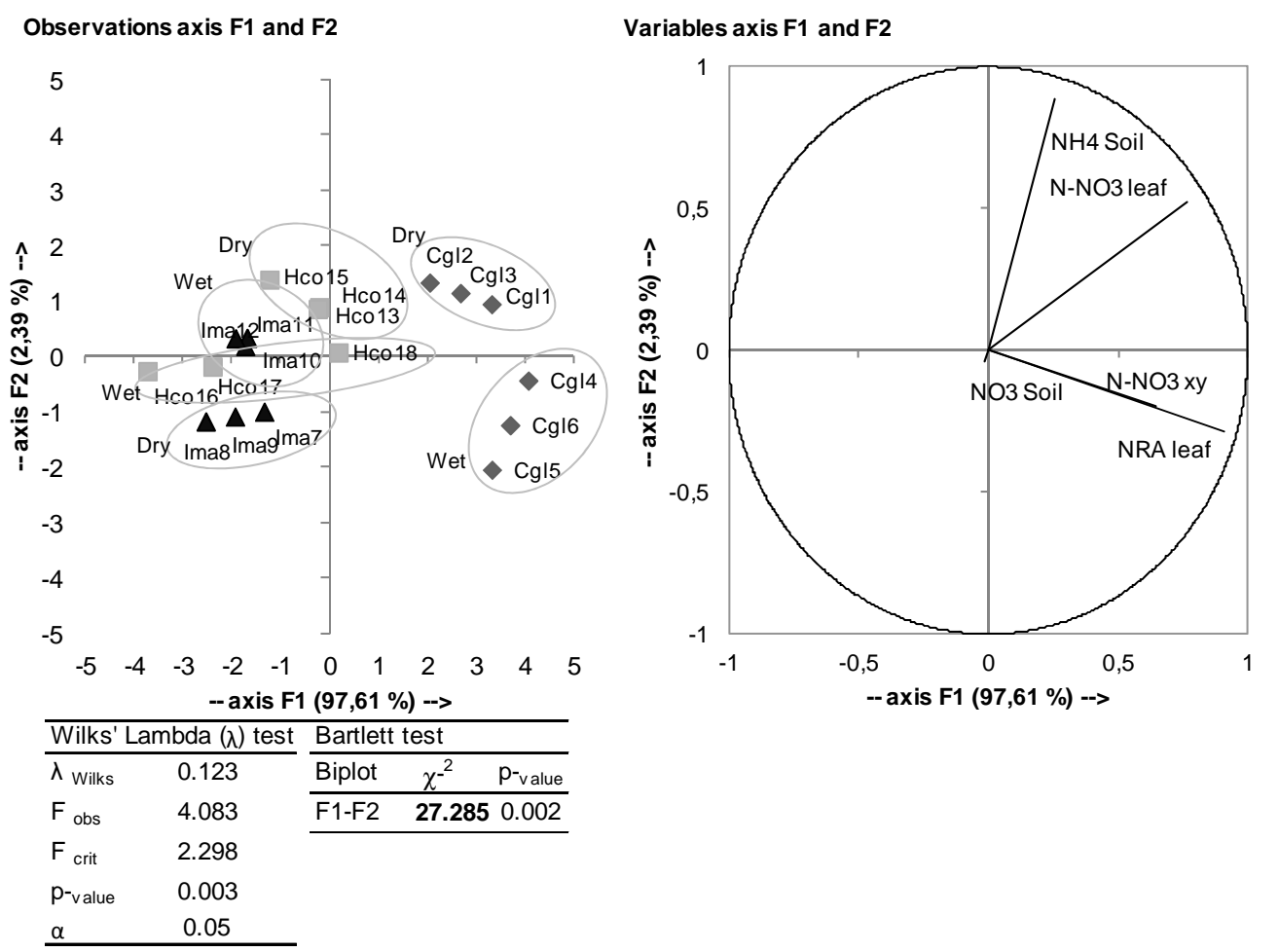

Figure 1. Biplot diagram of the factorial discriminant analysis (FDA) indicating the correlation between nitrogen use variables for each

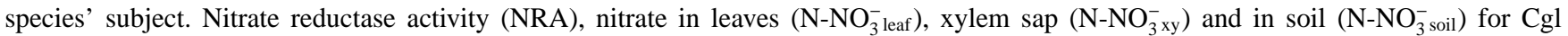
(Cecropia glaziovi), Ima (Inga marginata) and Hco (Hymenaea courbaril).

would be of great importance, since $\mathrm{Cgl}$ is a species commonly used in ecological restoration projects.

The greater responsiveness of $\mathrm{Cgl}$ to $\mathrm{N}-\mathrm{NO}_{3}^{-}$can be attributed to the behaviour of pioneer species that develop under sunlight since photosynthesis generates energy through carbon skeletons (Quilici and Medina, 1998). The N-NO absorption by the leaves can be driven primarily by the transport of photosynthesis' electrons, which results in low carbon costs for the plant (Bloom et al., 1992). As seen in the results, $\mathrm{Cgl}$ had a high content of $\mathrm{N}^{-\mathrm{NO}_{3}^{-}}$, even though this ion was available in a low quantity in the soil, principally in the dry season (Tables 2 and 3; Fig. 1). The high $\mathrm{N}^{-\mathrm{NO}_{3}-}$ content in $\mathrm{Cgl}$ leaves can be related to the levels of xylem transport (Table 3). This process depends on transpiration to allow the outflow of $\mathrm{N}-\mathrm{NO}_{3}^{-}$and other products absorbed by the roots (Sodek, 2004). Our results support the findings of previous research with tropical and sub-tropical species that highlighted the importance of leaves as a $\mathrm{N}^{-\mathrm{NO}_{3}^{-}}$assimilation compartment in species with elevated foliar NRA (Harper, 1994). The N-NO- uptake can be the bottleneck between the source in the soil solution and the assimilatory pathway in the plants (Touraine, 2004). In terms of nitrogen nutrition, the use of $\mathrm{Cgl}$ can represent a key element to the success of ecological restorations.

Like many native leguminous genera in tropical ecosystems, Ima can form a symbiotic relationship with $\mathrm{N}_{2}$-fixing bacteria from the genera Rhizobium and Bradyrhizobium (Faria et al., 1989; Moreira et al., 1992; Gonçalves et al., 1999). This may explain the lack of responsiveness to N$\mathrm{NO}_{3}^{-}$(Table 3, Fig. 1). Less dependence on available nitrogen

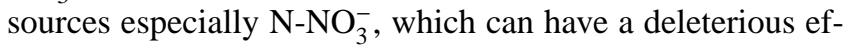
fect on nodules, may explain its wide distribution in natural communities and their ability to colonize less fertile environments (Gonçalves et al., 1999). Along with these observations, its tolerance to acidity (Lawrence et al., 1995) and temporary waterlogging and flooding of the soil (Durigan and Nogueira, 1990) favor the use of Ima in the recovery of degraded areas, especially since this species can assist in incorporating nitrogen in the soil and, therefore, in the growth of other plants.

The low responsiveness of the late secondary species, Hco, to $\mathrm{N}^{-\mathrm{NO}_{3}^{-}}$may have different explanations. One of them is the high efficiency of nitrogen resorption observed by Lima et al. (2006) combined with the longer life of its leaves, which represents a form of nutrient conservation and mineral loss reduction during senescence and leaf fall (Aerts, 1996; Carrera et al., 2003; Eckstein et al., 1999, Lima et al., 2006). This is an important adaptation mechanism (May and Killingbeck, 1992; Pugnaire and Chapin, 1993) that favors its use in the recolonization of low fertility soils (Aerts, 1996; Eamus and Prichard, 1998). Furthermore, the fact that this species does not form symbiotic associations, either through 
nodulation (Leitão, 1997) or through mycorrhiza (Carneiro et al., 1998), suggests the absorption of other nitrogen forms from the soil, such as $\mathrm{N}-\mathrm{NH}_{4}^{+}$or organic nitrogen, not evaluated in this study. In this experiment, the lack of relationships between the $\mathrm{N}^{-\mathrm{NO}_{3}^{-}}$availability in the soil and the consumption, accumulation, and transport by the plant (Table 4), combined for low NRA values (Table 3). This reinforced the idea that this species performs internal nitrogen remobilisation and/or uses the soil $\mathrm{N}-\mathrm{NH}_{4}^{+}$content kept constant during the period (Table 2).

The soil-plant relationships of nitrogen use observed in the studied species had results consistent with those suggested by the literature for their successional types. Studies showed that, in general, pioneer species, such as $\mathrm{Cgl}$, have a preference for $\mathrm{N}^{-\mathrm{NO}_{3}^{-}}$as their nitrogen source and have high levels of NRA. However, secondary species, such as Ima and Hco, have relatively low levels of this enzyme and a lower affin-

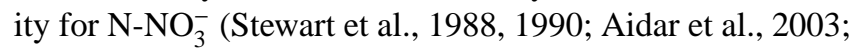
Pereira-Silva et al., 2011). Therefore, we highlight that variables such as NRA in plants and soil $\mathrm{N}_{-} \mathrm{NO}_{3}^{-}$content can indicate the form of nitrogen nutrition appropriate for ecological restoration projects.

All of the studied species are well adapted to the soil conditions and are commonly used as riparian woody buffers because of their growth time and intrinsic ability to uptake the different available nitrogen forms. The choice of species to be used in the recovery of degraded areas must be dependent on the climatic and edaphic conditions of the area (Resende and Kondo, 2001). Knowledge of the responsiveness to available nitrogen is critical in this selection since it allows the use of species with a performance more suited to the degradation peculiarities and environmental limitations of the degraded soils whose nutrient and edaphic conditions are compromised. This would facilitate the establishment of a floristic heterogeneity for the future onset of the succession dynamics, which will ensure the maintenance of the ecological functions of these areas.

\section{Conclusions}

The tropical trees studied differ in the ecophysiology of nitrogen use. The pioneer species $C$. glaziovi was more respon-

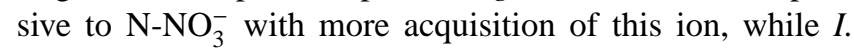
marginata and $H$. courbaril (secondary species) showed low responsiveness, with less use of $\mathrm{N}^{-\mathrm{NO}_{3}^{-}}$and low levels of nitrate reductase. These results indicate a decreasing dependence for each species $(\mathrm{Cgl} \gg \mathrm{Ima}>\mathrm{Hco})$ between variables related to the reduction, content and transport of $\mathrm{N}^{-\mathrm{NO}_{3}^{-}}$in leaves and availability in soil.
Acknowledgements. The authors acknowledge the support received from FMPFM (Faculdade Municipal Franco Montoro) through of financial assistence. We also thank the help of the editors and the two anonymous referees who helped us to improve the manuscript.

Edited by: F. Valladares

Reviewed by: two anonymous referees

\section{References}

Aerts, R.: Nutrient resorption from senescing leaves of perennials: are there general patterns?, J. Ecol., 84, 597-608, 1996.

Aidar, M. P. M., Schmidt, S., Moss, G., Stewart, G. R., and Joly, C. A.: Nitrogen use strategies of neotropical rainforest trees in threatened Atlantic Forest, Plant Cell Environ., 26, 389-400, 2003.

Bloom, A. J., Sukrapanna, S. S., and Warner, R. L.: Root respiration associated with ammonium and nitrate absorption and assimilation by barley, Plant Physiol., 99, 1294-1301, 1992.

Carneiro, M. A. C., Siqueira, J. O., Moreira, F. M. S., Carvalho, D., Botelho, S. A., and Junior, O. J. S.: Micorríza arbuscular em espécies arbóreas e arbustivas nativas de ocorrência no sudeste do Brasil, Revista Cerne, 1, 129-145, 1998.

Carrera, A. L., Bertiller, M. B., Sain, C. L., and Mazzarino, M. J.: Relationship between plant nitrogen conservation mechanisms and the dynamics of soil nitrogen in the arid Patagonian Monte, Argentina. Plant Soil, 255, 595-604, 2003.

Cataldo, D., Haaron, M., Scharader, L. E., and Youngs, V. L.: Rapid colorimetric determination of nitrate in plant tissue by nitration of salicylic acid, Commun Soil Sci. Plan., 6, 71-80, 1975.

CIIAGRO online 2010: Centro Integrado de Informações Agrometeorológicas do Instituto Agronômico de Campinas, http://www. ciiagro.sp.gov.br (last access: July 2012), 2010.

Delitti, W. B. C. and Burger, D. M.: Carbon and nutrient pools in a gallery forest at Mogi Guaçu River, Southeast Brazil, Ann. For. Sci., 57, 39-48, 2000.

Dijkstra, F. A., Blumenthal, D., Morgan, J. A., Pendall, E., Carrillo, Y., and Follett, R. F.: Contrasting effects of elevated $\mathrm{CO}_{2}$ and warming on nitrogen cycling in a semiarid grassland, New Phytol., 187, 426-437, 2010.

Durigan, G. and Nogueira, J. C. B.: Recomposição de matas ciliares, IF: série registros, São Paulo, 1-14, 1990.

Eamus, D. and Prichard, H. A.: Cost-benefit analysis of leaves of four Australian savanna species, Tree Physiol. 18, 537-545, 1998.

Eckstein, R. L., Karlsson, P. S., and Weih, M.: Leaf life span and nutrient resorption as determinants of plant nutrient conservation in temperate-arctic regions, New Phytol., 143, 177-189, 1999.

EMBRAPA - Empresa Brasileira de Pesquisa Agropecuária: Sistema brasileiro de classificação de solos, 2nd Edn., Rio de Janeiro, Embrapa Solos, 306 pp., 2006.

Faria, S. M., Lewis, G. P., Sprent, J. I., and Sutherland, J. M.: Ocurrence of nodulation in the Leguminosae, New Phytol., 111, 607619, 1989.

Genú, A. M., Demattê, J. A. M., and Fiorio, P. R.: Spectral analysis of soils from Mogi-Guaçú (SP) Region, Semina: Ciências Agrárias, 31, 1235-1244, 2010. 
Gonçalves, C. A., Goi, S. R., and Jacob Neto, J.: Crescimento e nodulação de Inga marginata em resposta à adição de nitrogênio, fósforo e inoculação com rizóbio, Floresta \& Ambiente, 6, 118126, 1999.

Haines, B. L.: Nitrogen uptake: apparent pattern during old field succession in southeastern United States, Oecologia, 26, 295303, 1977.

Harper, J. E.: Nitrogen metabolism, in: Physiology and determination of crop yield, edited by: Boote, K. J., American Society of Agronomy, Madison, 285-302, 1994.

Hartz, T. K., Bendixen, W. E., and Wierdsma, L.: The value of preside dress soil nitrate as a nitrogen management tool in irrigated vegetable production, HortScience, 35, 651-656, 2000.

Kielland, K.: Amino acids absorption by arctic plants: implications for plant nutrition and nitrogen cycling, Ecology, 75, 2373-2383, 1994.

Koyama, L., Tokuchi, N., Hirobe, M., and Koba, K.: The potential of $\mathrm{NO}_{3}^{-} \mathrm{N}$ utilization by a woody shrub species Lindera triloba: A cultivation test to estimate the saturation point of soil $\mathrm{NO}_{3}^{-}$for plants, The Sci. World J., 1, 514-519, 2001.

Kronzucker, H. J., Siddiqi, M. Y., and Glass, A. D. M.: Root discrimination against soil nitrate and the ecology of forest succession, Nature, 385, 59-61, 1997.

Lamb, D.: Soil nitrogen mineralization in a secondary rainforest succession, Oecologia, 47, 257-263, 1980.

Lawrence, A., Pennington, T. D., Hands, M. R., and Zúniga, R. A.: Inga: High diversity in the neotropics nitrogen fixing trees for acid soils, Nitrogen fixing tree Research Reports Special Issue, 130-141, 1995.

Lee, J. A. and Stewart, G. R.: Ecological aspects of nitrogen assimilation, Adv. Bot. Res., 6, 1-43, 1978.

Leitão, M. R. S. M. M.: Fixação biológica de nitrogênio por espécies arbóreas, in: Biologia dos solos dos cerrados, edited by: Vargas, M. A. T. and Hungria, M., Embrapa, Brasília, 155-186, 1997.

Lima, A. L. S., Zanella, F., Schiavianto, M. A., and Haddad, C. R. B.: $\mathrm{N}$ availability and mechanisms of $\mathrm{N}$ conservation in deciduous andsemideciduous tropical forest legume trees, Acta Bot. Bras., 20, 625-632, 2006.

Malavolta, E., Vitti, G. C., and Oliveira, S. A.: Avaliação do estado nutricional das plantas, Potafos, Piracicaba, 1997.

Marschner, M.: Mineral Nutrition of Higher Plants, Academic Press, New York, 1995.

May, J. D. and Killingbeck, K. T.: Effects of preventing nutrient resorption on plant fitness and foliar nutrient dynamics, Ecology, 73, 1868-1878, 1992.

Moreira, F. M. S., Silva, M. F., and Faria, S. M.: Ocurrence of nodulation in legume species in the Amazon Region of Brazil, New Phytol., 121, 563-570, 1992.

Niboyet, A., Le Roux, X., Dijkstra, P., Hungate, B. A., Barthes, L., Blankinship, J. C., Brown, J. R., Field, C. B., and Leadley, P. W.: Testing interactive effects of global environmental changes on soil nitrogen cycling, Ecosphere, 2, 1-24, 2011.

Nieder, R. and Benbi, D. K.: Carbon and nitrogen transformations in soils, in: Carbon and Nitrogen in the Terrestrial Environment, edited by: Nieder, R. and Benbi, D. K., Springer Netherlands, 137-159, 2008.

Onken, A. and Sunderman, H. D.: Colorimetric determinations of exchangeable ammonium, urea, nitrate, and nitrite in a single soil extract, Agron. J., 69, 49-53, 1977.

Pate, J. S.: Transport and portioning of nitrogenous solutes, Annu. Rev. Plant Physiol., 31, 313-340, 1980.

Pereira-Silva, E. F. L., Santos, J. E., Hardt, E., and Aidar, M. P. M.: Atividade de Nitrato Redutase e conteúdo de nitrogênio em folhas de espécies arbóreas de cerradão da Estação Ecológica de Jataí, Luiz Antônio, SP, in: Estudos integrados em ecossistemas - Estação Ecológica de Jataí, edited by: Santos, J. E., Pires, J. S. R., and Moschini, L. E., EdUFSCar, São Carlos, 3, 65-79, 2006.

Pereira-Silva, E. F. L., Hardt, E., Aidar, M. P. M., and Joly, C. A.: Sucessão ecológica e o uso de nitrogênio em florestas tropicais, Revista Interciência \& Sociedade, 1, 149-159, 2011.

Pugnaire, F. I. and Chapin, F. S.: Controls over nutrient resorption from leaves of evergreen Mediterranean species, Ecology, 74, 124-129, 1993.

Quilici, A. and Medina, E.: Photosynthesis-nitrogen relationships in pioneer plants of disturbed tropical montane forest sites, Photosynthetica, 35, 525-534, 1998.

Resende, A. V. and Kondo, M. K.: Leguminosas e recuperação de áreas degradadas, Informe Agropecuário, 22, 46-56, 2001.

Robertson, G. P. and Vitousek, P. M.: Nitrification potentials in primary and secondary succession, Ecology, 62, 376-386, 1981.

Schimann, H., Ponton, S., Hättenschwiler, S., Ferry, B., Lensi, R., Domenach, A. M., and Roggy, J. C.: Differing nitrogen use strategies of two tropical rainforest late successional tree species in French Guiana: Evidence from 15N natural abundance and microbial activities, Soil Biol. Biochem., 40, 487-494, 2008.

Schmidt, S. and Stewart, G. R.: Transport, storage and mobilization of nitrogen by trees and shrubs in the wet/dry tropics of northern Australia, Tree Physiol., 18, 403-410, 1998.

Smirnoff, N. and Stewart, G. R.: Nitrate assimilation and translocation by higher plants: Comparative physiology and ecological consequences, Physiol. Plantarum, 64, 133-140, 1985.

Smirnoff, N., Tood, P., and Stewart, G. R.: The occcurrence of nitrate reduction in the leaves of woody plants, Ann. Bot., 54, 363374, 1984.

Smith, J. L. and Rice, E. L.: Differences in nitrate reductase activity between species of difference stages in old field succession, Oecologia, 57, 43-48, 1983.

Sodek, L.: Metabolismo do nitrogênio, in: Fisiologia vegetal, edited by: Kerbauy, G. B., Guanabara Koogan, Rio de Janeiro, 94-113, 2004.

Stewart, G. R.: Localization of nitrate reduction in ferns and its relationship to environment and physiological characteristics, The New Phytol., 104, 373-384, 1986.

Stewart, G. R., Hegarty, E. E., and Specht, R. L.: Inorganic nitrogen assimilation in plants of Australian rainforest communities, Physiol. Plant, 74, 26-33, 1988.

Stewart, G. R., Gracia, C. A, Hegarty, E. E., and Specht, R. L.: Nitrate reductase and chlorophyll content in sun leaves of subtropical Australian closed-forest (rainforest) and open-forest communities, Oecologia, 82, 544-551, 1990.

Stewart, G. R., Joly, C. A., and Smirnoff, N.: Partitioning of inorganic nitrogen assimilation between the roots and shoots of cerrado and forest trees of contrasting plant communities of South East Brazil, Oecologia, 91, 511-517, 1992.

Stewart, G. R., Pates, J. S., and Unkovich, M.: Characteristics of inorganic nitrogen assimilation of plants in fire-prone Mediterranean type vegetation, Plant Cell Environ., 16, 351-363, 1993. 
Taiz, L. and Zeiger, E.: Plant physiology, Sinauer associates, Califórnia, 2002.

Tilman, D. and Wedin, D.: Dynamics of nitrogen competition between successional grasses, Ecology, 72, 1038-1049, 1991.

Touraine, B.: Nitrate uptake by roots-transporters and root development, in: Nitrogen Acquisition and Assimilation in Higher Plants, edited by: Amâncio, S. and Stulen, I., Kluwer Academic Publishers, The Netherlands, 1-34, 2004.
Usman, S., Singh, S. P., and Rawat, Y. S.: Nitrification mineralization and inorganic-N uptake in evergreen forests of the central Himalayas, Eur. J. Soil Biol., 36, 65-71, 2000. 